\title{
Utilization of solar UV radiation by coastal phytoplankton assemblages off SE China when exposed to fast mixing
}

\author{
E. Walter Helbling ${ }^{1,2, *}$, Kunshan Gao ${ }^{1}$, Rodrigo J. Gonçalves ${ }^{2}$, Hongyan $\mathrm{Wu}^{1}$, \\ Virginia E. Villafañe ${ }^{1,2}$ \\ ${ }^{1}$ Marine Biology Institute, Shantou University, Shantou, Guangdong 515063, PR China \\ ${ }^{2}$ Estación de Fotobiología Playa Unión and Consejo Nacional de Investigaciones Científicas y Técnicas (CONICET), \\ Rifleros 227, Playa Unión (9103) Rawson, Chubut, Argentina
}

\begin{abstract}
During May 2002 we carried out studies with tropical phytoplankton assemblages from coastal waters off SE China to assess the combined effects of solar UV radiation (UVR, 280 to $400 \mathrm{~nm}$ ) and mixing rates. Water samples were taken daily and incubated using in situ and simulated in situ conditions under 3 radiation regimes (photosynthetically active radiation [PAR] + UVR, PAR + UV-A and PAR only). Variable radiation regimes, to simulate the irradiance field in the upper mixed layer (UML), were obtained by using a device consisting of 1 fixed (static samples) and 1 rotating system (moving samples). Solar UVR inhibited phytoplankton photosynthesis in the water column (i.e. during in situ experiments), and this inhibition (mean value at surface $=24 \%$ ) decreased with depth, so that at $1.2 \mathrm{~m}$ there were no significant differences between radiation treatments. However, at $1.8 \mathrm{~m}$ depth, the samples receiving UV-A had significantly higher carbon fixation than those receiving only PAR. Simulated in situ experiments showed that solar UVR stimulated phytoplankton photosynthesis under fast mixing conditions (i.e. when the irradiance levels changed from 100 to $6 \%$ and back in less than $30 \mathrm{~min}$ ). With slower circulation periods, solar UVR reduced carbon fixation and consequently the integrated inhibition within the UML approached the values from the static samples. Previous model predictions based on the interactive effects of UVR and mixing might have underestimated phytoplankton photosynthesis in these regions. Overall, our results suggest a high resistance of these coastal tropical assemblages to solar UVR as compared to other regions of the planet.
\end{abstract}

KEY WORDS: UVR · Mixing $\cdot$ Phytoplankton $\cdot$ Photosynthesis $\cdot$ South China Sea

\section{INTRODUCTION}

Solar ultraviolet radiation (UVR, 280 to $400 \mathrm{~nm}$ ) is an environmental factor that has a range of effects upon phytoplanktonic organisms. These effects can be: positive, such as those that are determined by an increase of carbon uptake under relatively low UVR levels (Nilawati et al. 1997, Barbieri et al. 2002) or by the use of UV-A to photorepair DNA damage (Karentz et al. 1991a); neutral, with many planktonic organisms being rather resistant to UVR (Cabrera et al. 1997); or even deleterious, with UVR affecting various targets within the cell (e.g. Photosystem II, DNA, proteins, etc.) (Neale 1987, Häder 1997, Vincent \& Neale 2000). Indirect effects, such as the breakdown of DOM due to UVR, might be viewed either as positive, as it may result in an increase in nutrient supply, or negative, because it may enhance water transparency and thus the irradiance received by the cells (Williamson et al. 1996). A vast number of investigations have been particularly devoted to determining the impact of UVR upon the photosynthetic process (see review of Villafañe et al. 2003), most of them stressing the reduction of carbon uptake under high irradiances. 
In spite of the great effort put forward to evaluate the impact of UVR upon phytoplankton photosynthesis, it is only relatively recently that photobiological research has focused on the interactions of UVR with other environmental factors. Mixing is one of such factors that can alter the effects produced solely by UVR, as phytoplanktonic cells are moved up and down and are thus exposed to a fluctuating irradiance regime from near surface irradiances to much lower values at the bottom of the upper mixed layer (UML). Mixing also conditions the mean UVR received by cells and determines the residence time of phytoplankton within the 'photoactive' zone (Neale et al. 2003). Previous studies carried out by Helbling et al. (1994) with Antarctic phytoplankton assemblages have demonstrated that shallow mixing greatly enhanced UVR-induced photosynthesis inhibition as compared to samples from deep mixing conditions. Neale et al. (1998) obtained similar results and further demonstrated that the effects of mixing upon photosynthesis were far more significant than those produced by changes in column ozone concentrations. Furthermore, the effects of variations of mixing rates have been modeled by Neale et al. (1998), and they concluded that fast mixing enhanced photoinhibition in Antarctic phytoplankton assemblages. Finally, Barbieri et al. (2002), working with temperate phytoplankton, have shown that the impact of UVR changed from negative to positive according to the portion of the euphotic zone $\left(E_{\mathrm{u}}\right)$ that was being mixed, so that with shallow mixing UVR reduced carbon fixation, whereas if $\sim 90 \%$ of the $E_{\mathrm{u}}$ was being mixed, UVR was used for photosynthesis.

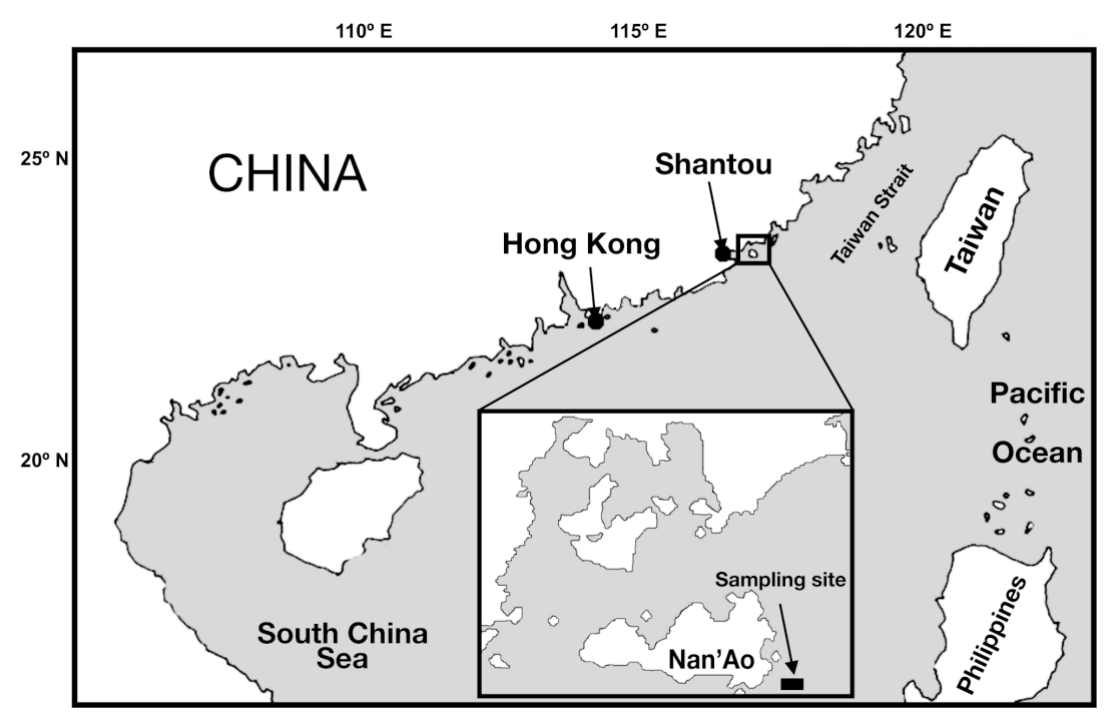

Fig. 1. Map of the South China Sea. Enlarged area is the Nan'Ao Island region, indicating the sampling and experimental site $(\boldsymbol{\square})$
The aim of this paper is to evaluate the combined effects of solar UVR and mixing rates upon $\mathrm{CO}_{2}$ uptake by coastal phytoplankton assemblages from waters off SE China. Phytoplankton in this area is normally exposed to high UVR conditions, not only because of the low zenith angles and low total ozone column concentrations (Madronich 1993) but also because of the downward trend in ozone concentration of $\sim 6 \%$ during the 11 yr solar cycle (Rozema et al. 2002), which brings about enhanced levels of solar UVR, especially in the UV-B (280 to $315 \mathrm{~nm}$ ) region.

\section{MATERIALS AND METHODS}

During May 2002 we conducted studies in the South China Sea (Fig. 1) to assess the interactive effects of solar UVR and vertical mixing upon phytoplankton primary productivity. Surface water samples were collected daily from a boat (early in the morning) using a clean $(1 \mathrm{~N} \mathrm{HCl})$ polycarbonate carboy used in experiments as described below.

Experiments. In situ incubations: A total of 4 in situ experiments were conducted with samples incubated at 4 depths in the water column. Water samples were dispensed in $50 \mathrm{ml}$ quartz tubes and inoculated with labeled radiocarbon to determine photosynthetic rates (see 'Analyses and measurements'). At each depth, 3 radiation treatments were implemented (duplicate samples for each treatment): (a) samples receiving full solar radiation (PAR + UVR), in uncovered quartz tubes; (b) samples receiving radiation $>320 \mathrm{~nm}$, in tubes covered with UV cut-off filter foil (Montagefolie, No. 10155099, Folex); and (c) samples receiving only PAR, in quartz tubes covered with Ultraphan film (UV Opak, Digefra). The transmission spectra of these filter foils have been published elsewhere (Figueroa et al. 1997). The tubes were held horizontally in aluminum frames (i.e. parallel to the water surface) and incubated for 3 to $4 \mathrm{~h}$ (centered on local noon) at 0, 0.6, 1.2 and $1.8 \mathrm{~m}$ depth in the water column.

Simulated in situ experiments: These experiments were carried out to determine UVR effects upon phytoplankton photosynthesis when exposed to simulated mixing conditions (i.e. variable irradiance field) and under maximum radiation levels (i.e. the worst-case scenario). The tubes containing samples were placed in a water bath with running surface seawater for temperature control. Two different sets of experiments were conducted using this set-up: 
(1) In variable irradiance experiments a device similar to that described in Helbling et al. (1994), consisting of 1 fixed (static samples), and 1 rotating system (moving samples) was used. Both systems had various layers of neutral density screens that allowed attenuation of incident radiation (from 100 to $6 \%$ in 5 discrete steeps), thus approximately simulating the UVR field received by cells in the top $2 \mathrm{~m}$ of the water column. We are aware that this system does not mimic the differential attenuation of UVR and PAR in the water column, but it provides, nevertheless, very useful information to accomplish the objective of this paper. Water samples were dispensed in $20 \mathrm{ml}$ quartz tubes and inoculated with labeled radiocarbon (see 'Analyses and measurements'). Each system had 2 radiation treatments, with duplicate samples exposed to (a) full solar radiation - PAR + UVR (uncovered quartz tubes), and (b) PAR only (quartz tubes covered with Ultraphan UV Opak Digefra film). The tubes in the fixed system (i.e. static samples) received 100, 50, 25, 12.5 and $6 \%$ of incident solar radiation during the whole incubation period ( 3 to $4 \mathrm{~h}$ ). At the beginning of each set of experiments, 2 tubes were wrapped in aluminum foil and incubated to determine dark $\mathrm{CO}_{2}$ uptake (i.e. during 3 and $4 \mathrm{~h}$, respectively). The turnover time of the wheel, and thus that of the filters in the rotating system, was obtained by using a step motor controlled by a microprocessor. The duration of each rotation (i.e. from 100 to 6 and back to $100 \%$ irradiance) varied from 10 to $120 \mathrm{~min}$. Thus, since the experiments lasted 3 and $4 \mathrm{~h}$, the number of rotations also varied: for example, for a turnover time of $10 \mathrm{~min}$, phytoplankton 'circulated' 18 and 24 times, respectively. A total of 12 combined experiments (i.e. fixed and rotating systems) were performed.

(2) To assess the wavelength dependence of photosynthetic inhibition (i.e. biological weighting functions, BWFs), phytoplankton samples were placed in $50 \mathrm{ml}$ quartz tubes and inoculated with labeled radiocarbon (see next subsection). The tubes (4 per treatment) were placed in a black aluminum frame under 6 radiation treatments: uncovered quartz tubes (receiving both PAR and UVR), and quartz tubes covered with various Schott sharp cut-off filters (WG295, WG305, WG320, WG360 and WG400 nm, the transmission spectra of these filters have been published in Villafañe et al. 2003). The BWF-PI model (Neale \& Kieber 2000) was used to calculate the BWF in our phytoplankton assemblages because the data indicated that the inhibition was a function of irradiance. The photosynthetic inhibition for each wavelength interval (i.e. carbon uptake in the tubes under each Schott filter compared with the PAR-only control) over the incubation period was expressed as a function of the average irradiance. The irradiance between each filter interval was determined with STAR software (Ruggaber et al. 1994, Dlugi et al. 1994) and with data from the ELDONET sensor. Spectral dependence of the BWF in broadband intervals was extracted using the method of Rundel (1983). An exponential decay function (Base 10) was used to fit the data in each experiment, and the exponent of the function was expressed as a third-degree polynomial function; the best fit was obtained by iteration (the smallest $\mathrm{R}^{2}$ obtained was 0.95). Five different and independent experiments were performed to determine BWFs, and from these data a mean BWF was obtained.

Analyses and measurements. The analytical procedure for each determination/measurement was as follows: (1) Photosynthetic rates: Samples contained in the quartz tubes were inoculated with $0.1 \mathrm{ml}$ of $5 \mu \mathrm{Ci}$ (0.185 MBq)-labeled sodium bicarbonate (ICN Radiochemicals). After incubation, the samples were filtered onto a Whatman GF/F glass fiber filter (25 mm). Then, the filters were placed in $20 \mathrm{ml}$ scintillation vials, exposed to $\mathrm{HCl}$ fumes overnight, dried, and counted using standard liquid scintillation techniques (HolmHansen \& Helbling 1995). (2) Chl a: This was measured by filtering 1 to 21 of water sample onto a Whatman GF/F glass fiber filter (47 mm), followed by extraction with absolute methanol for $2 \mathrm{~h}$ and subsequent determination of the optical density (OD) in a scanning spectrophotometer (Shimadzu UV 2501-PC). Chl a concentration was calculated using the equations of Wellburn (1994). (3) Floristic analysis: Water samples were taken daily and fixed with Lugol's solution. The quantitative analysis of phytoplankton cells was carried out using an inverted microscope (Utermöhl 1958). The samples $(10 \mathrm{ml})$ were settled for $24 \mathrm{~h}$ and counted following the methodology described in Villafañe \& Reid (1995). (4) Radiation measurements: Incident solar radiation was continuously measured using a filter radiometer (ELDONET, Real Time Computers) (Häder et al. 1999). The instrument records irradiance in 3 wavelength bands: UV-B (280 to $315 \mathrm{~nm}), \mathrm{UV}-\mathrm{A}$ (315 to $400 \mathrm{~nm}$ ), and PAR (400 to $700 \mathrm{~nm}$ ), and also has a temperature and depth channel. This profiling instrument was also used to determine the underwater radiation field.

\section{RESULTS}

A representative profile of the underwater radiation field in our coastal sampling site near Nan'Ao Island is shown in Fig. 2. Both UV-B and UV-A were rapidly attenuated in the water column, with the $1 \%$ level of surface irradiance found at 2.5 and $2.87 \mathrm{~m}$, respectively. PAR penetrated much deeper, and the euphotic zone ( $1 \%$ of surface PAR) was determined at $6.6 \mathrm{~m}$ 
Irradiance $\left(\mathbf{W} \mathbf{m}^{-2}\right)$

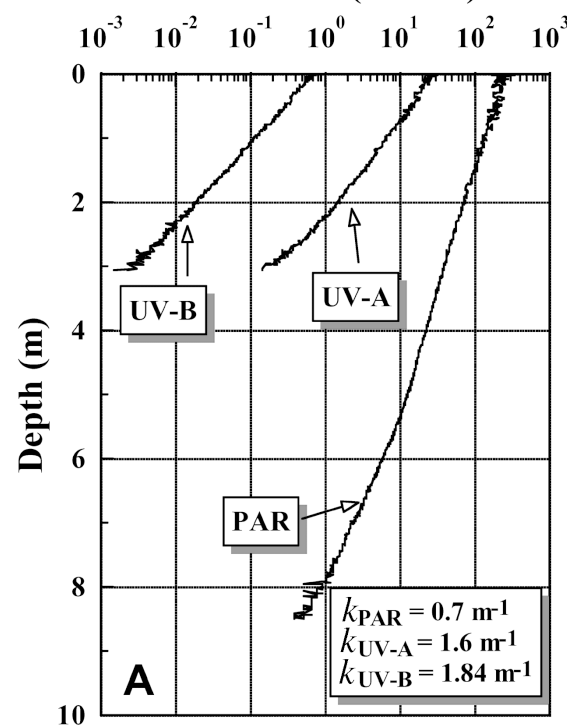

Temperature $\left({ }^{\circ} \mathrm{C}\right)$

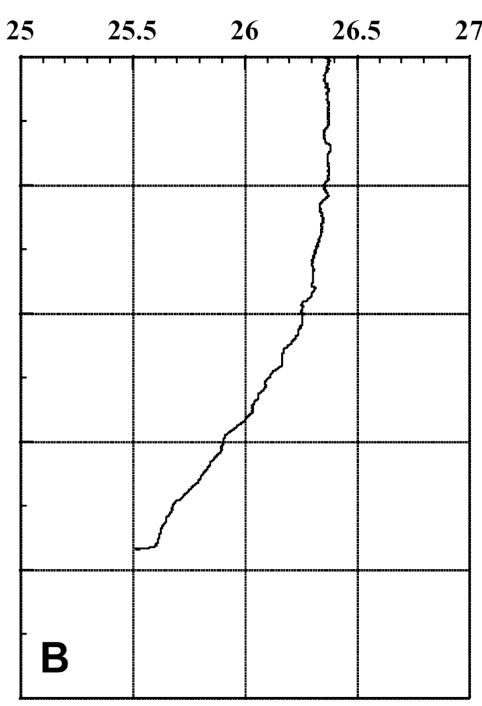

Fig. 2. (A) Representative underwater radiation profile (UV-B, UV-A and photosynthetically active radiation [PAR]) in the upper $10 \mathrm{~m}$ of the water column. Inset shows the attenuation coefficients $(k)$ for these wavebands. (B) Representative temperature profile for the upper $10 \mathrm{~m}$ of the water column

(Fig. 2A). Attenuation coefficients for PAR, UV-A and UV-B were $0.7,1.6$ and $1.84 \mathrm{~m}^{-1}$, respectively. Water temperature was rather constant down to $\sim 4 \mathrm{~m}$, and below this depth the temperature decreased gradually (Fig. 2B). During our study period the mean incident UVR $\left(E_{\mathrm{UVR}}\right)$ and PAR $\left(E_{\mathrm{PAR}}\right)$ were 51 and $306 \mathrm{~W} \mathrm{~m}^{-2}$, respectively, and the mean total ozone column concentration was 285 Dobson Units (data obtained from http://jwocky.gsfc.nasa.gov/).

The in situ impact of solar radiation on carbon fixation per unit chl a per hour (i.e. the assimilation number) is shown in Fig. 3. The contribution of UV-B and UV-A to the photosynthetic inhibition at the surface was similar, and the mean inhibition by UVR was $24 \%$. Photosynthetic inhibition decreased with depth so that no negative effects of UV-B or UV-A were observed at $1.2 \mathrm{~m}$ (i.e. optical depth of 0.84 ) where the irradiance for these wavebands $\left(E_{\mathrm{UVR}}\right)$ was approximately $6 \%$ of that at the surface. Below this depth, the assimilation numbers in the samples that were exposed to PAR + UVR or PAR + UV-A were significantly higher than in the samples exposed to PAR only $(p<0.05)$. There was no significant difference $(p>0.05)$ between samples exposed to UV-A or UVR at $1.8 \mathrm{~m}$, suggesting that the increase in carbon fixation per unit chl $a$ was due to UV-A radiation. Chl a concentration during the study period varied from 1.7 to $3.1 \mu \mathrm{g} \mathrm{l}^{-1}, 2.17 \mu \mathrm{g} \mathrm{l}^{-1}$ being the mean value during the study period. Floristic analysis of our samples revealed the dominance of the centric diatoms Chaetoceros spp. and Skeletonema sp. (mean

effective cell diameter $<10 \mu \mathrm{m})$. Other diatoms (e.g. Guinardia spp., Asterionellopsis sp., Rhizosolenia spp.) and dinoflagellates from the genera Ceratium, Protoperidinium and Noctiluca were also present, but never accounted for a significant proportion of the total cell numbers, as also occurred with monads and flagellates. The mean total cells during our experiments were 738 cells $\mathrm{ml}^{-1}$.

Simulated in situ mixing within the UML either enhanced or decreased carbon fixation in cells exposed to solar UVR (Fig. 4). Under fast mixing (1 complete turn: $100 \times 6 \times 100 \%$ irradiance in less than $30 \mathrm{~min})$, the samples that were exposed to PAR + UVR had significantly higher $(\mathrm{p}<$ $0.05)$ integrated carbon fixation per unit energy than those exposed only to PAR (i.e. negative values in Fig. 4). With increasing duration for each turn (i.e. slow mixing), the inhibition of carbon fixation due to UVR increased (i.e. positive values in Fig. 4), and the differences between PAR + UVR exposed and PAR-only

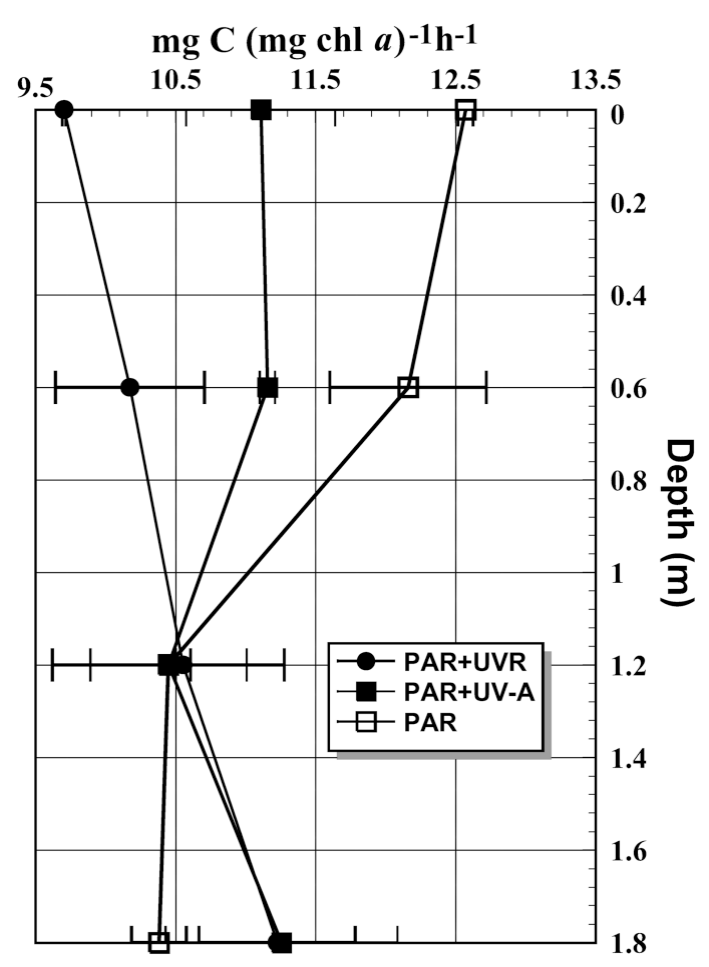

Fig. 3. Depth distribution of assimilation numbers $(\mathrm{mg} \mathrm{C} \mathrm{mg}$ chl $a^{-1} \mathrm{~h}^{-1}$ ) for samples exposed to photosynthetically active radiation (PAR) + UV-A + UV-B, PAR + UV-A, and PAR only. Horizontal bars represent SD 


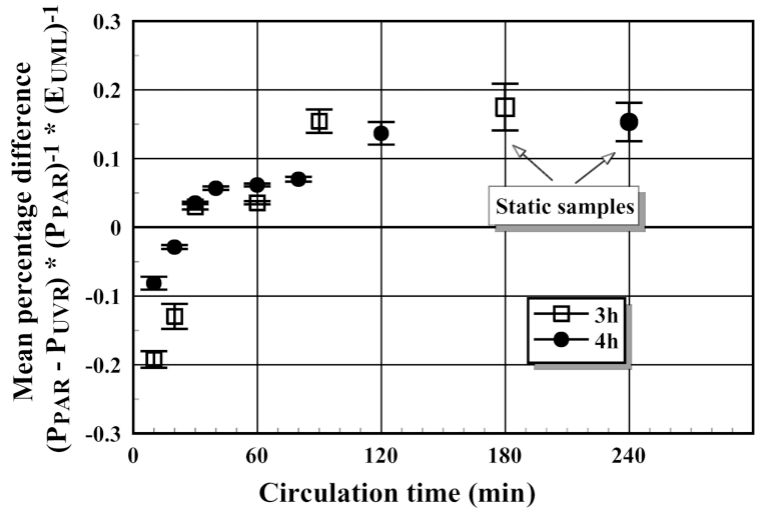

Fig. 4. Inhibition of phytoplankton photosynthesis due to UV radiation (UVR) as a function of circulation time within a simulated upper mixed layer (UML). Each point represents the mean integrated (i.e. $6 \%$ irradiance) carbon fixation difference between samples exposed to UVR $\left(P_{\mathrm{UVR}}\right)$ and those exposed only to photosynthetically active radiation (PAR) $\left(P_{\mathrm{PAR}}\right)$. Data were normalized by the mean irradiance (PAR) in the UML $\left(E_{\mathrm{UML}}\right)$ to account for variations in incident solar radiation. Negative values in the $y$-axis represent higher integrated carbon incorporation per unit energy of UVR in samples exposed to UVR. Experiments $(n=12$ ) lasted 3 (open symbols) or $4 \mathrm{~h}$ (solid symbols). Bars represent $\mathrm{SD}$

exposed samples approached the integrated inhibition values of the static samples. This response was observed in experiments that lasted 3 and $4 \mathrm{~h}$ (open squares and filled circles, respectively, in Fig. 4).

Results from BWFs (Fig. 5) suggest a relatively low impact of solar UVR in the tropical coastal phytoplankton assemblages from the SE China Sea, as compared to phytoplankton from other environments such as the tropical, high-altitude Lake Titicaca in Bolivia, and Antarctica. This low vulnerability of phytoplankton from the South China Sea was especially evident for wavelengths $>300 \mathrm{~nm}$, as the biological weights were much lower than those in the other sites. However, at shorter wavelengths, Antarctic assemblages seemed to be more resistant than phytoplankton from our experiments.

\section{DISCUSSION}

Since the early studies of Marra (1978) it was realized that phytoplankton production was affected by mixing, with carbon uptake being higher in the samples moving within UML than those kept static in the water column (i.e. static versus rotating incubations). These studies, however, considered only the effects of variable PAR regimes and did not address how fluctuating UVR might impact phytoplankton primary production. In fact, it is relatively recently that UVR has been considered an important factor that can also alter $\mathrm{CO}_{2}$ uptake by phytoplankton. Moreover, from the vast UVR literature, very few studies have concentrated on the interactive effects of UVR and mixing when the cells are moving in the UML, thus exposed to variable radiation regimes (Helbling et al. 1994, Neale et al. 1998, Köhler et al. 2001, Barbieri et al. 2002). For example, the studies of Helbling et al. (1994) and of Neale et al. (1998) in Antarctica concluded that, compared to fixed-depth incubations, vertical mixing reduced integrated primary productivity, with UVR effects being more severe under rapid mixing conditions (Neale et al. 1998, 2003). The exposure response of phytoplankton assemblages in these latter studies was based on the dose received by the cells (i.e. with no or very little repair) and thus, under rapid mixing, cells were exposed more frequently to high radiation levels, and consequently were more damaged.

Contrasting with these previous findings, we report here that the productivity of tropical coastal phytoplankton assemblages increased when exposed to UVR (i.e. mainly to UV-A) under simulated fast mixing conditions (Fig. 4). Based on the attenuation coefficients used to estimate the depth of the $6 \%$ irradiance level (i.e. bottom of our simulated mixing) we can visualize 2 extreme radiation-field scenarios under which the cells were exposed. In the first case, and considering an attenuation coefficient for UV-A $\left(k_{\mathrm{UV}-\mathrm{A}}\right)$ of $1.6 \mathrm{~m}^{-1}$, the $6 \%$ irradiance level would be found at $\sim 1.8 \mathrm{~m}$ in the water column (Fig. 2). In the second case, considering an attenuation coefficient for PAR ( $\left.k_{\text {PAR }}\right)$ of $0.7 \mathrm{~m}^{-1}$, this irradiance level would correspond to $\sim 4 \mathrm{~m}$ depth (Fig. 2). For the first option (i.e. mixing down to $1.8 \mathrm{~m}$ ),

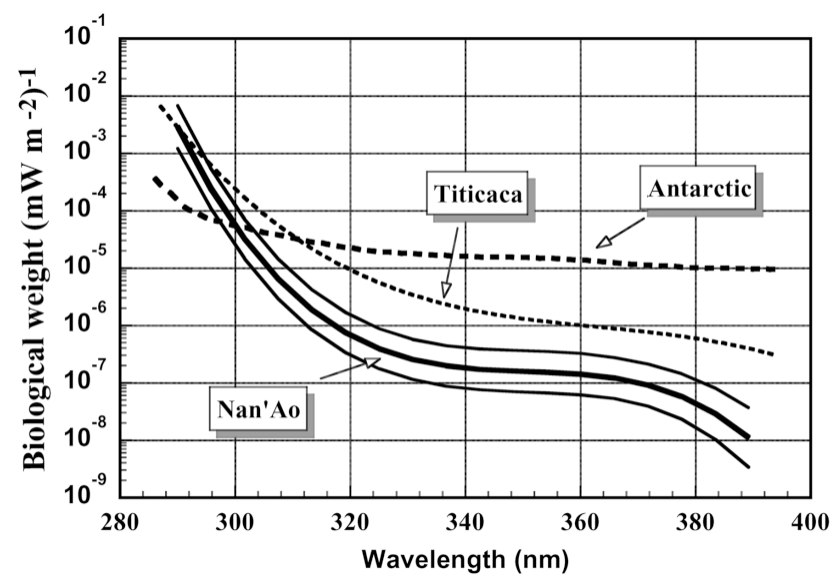

Fig. 5. Mean biological weighting function $\left(\left[\mathrm{mW} \mathrm{m}^{-2}\right]^{-1}\right)$ for phytoplankton from South China Sea waters, Nan'Ao area. Thin lines indicate $95 \%$ confidence limit. Biological weighting functions (BWFs) for natural populations of Antarctic (from Neale et al. 1994) and Lake Titicaca phytoplankton (Helbling et al. 2001a) are shown as comparisons 
the PAR level in the water column would be higher than that used in our simulated in situ experiments (i.e. $28 \%$ vs $6 \%$, respectively), whereas when using the simulated mixing depth of $4 \mathrm{~m}$ (i.e. based on $k_{\mathrm{PAR}}$ ), the UVR energy received by the cells in the simulated in situ experiments would be higher than that in the water column. In our study, however, we found the fact rather surprising that during the in situ experiments (Fig. 3), phytoplankton at $1.8 \mathrm{~m}$ depth were already using UV-A energy, in spite of the high irradiances normally received in this tropical environment. One can speculate that because of these high irradiances our phytoplankton assemblages were acclimated to high levels of solar radiation, leading to light-adapted cells with high optimal irradiance $\left(I_{k}\right)$. In any of these 'methodological extremes', our data clearly indicate that coastal phytoplankton assemblages, as with those used in our experiments, did utilize solar UV-A for photosynthesis (Fig. 3) when exposed to fast simulated mixing (Fig. 4). However, and based on the temperature profile (Fig. 2B), the second scenario would be more likely (i.e. with cells moving down to $4 \mathrm{~m}$ ). The use of UV-A in photosynthesis is in agreement with studies that determined the action spectra for chl a fluorescence together with oxygen evolution (e.g. Neori et al. 1986, 1988), although these studies did not consider the fluctuating radiation regime in the UML. Field studies in a temperate marine environment (e.g. Barbieri et al. 2002) also showed an increase in carbon uptake for samples exposed to UVA, and this was associated to the fact that low PAR levels, as occurring during winter, did not provide enough energy for photosynthesis.

Results from in situ incubations (Fig. 3), as well as from the BWF (Fig. 5), show the relative resistance to UVR of these tropical assemblages as compared to other environments. For example, phytoplankton from Antarctica, which is normally exposed to relatively low irradiances but is affected by ozone depletion events (Smith et al. 1992, Neale et al. 1998), is in general more sensitive to UVR than that from tropical sites, such as from Lake Titicaca (Villafañe et al. 1999, Helbling et al. 2001a) and reported here in our experiments in South China Sea waters. Moreover, the coastal assemblages off SE China waters are more resistant to UVR than those from the high-altitude Lake Titicaca. In addition, the results of static incubations (Fig. 3) showed that only a small portion of the euphotic zone would be affected by UVR (i.e. the upper 0.84 optical depth: 1.2 $\mathrm{m})$, in contrast with findings from Subantarctic sites, such as Beagle Channel (Villafañe et al. 2001) and Lake Titicaca (Helbling et al. 2001a), where UVR can negatively affect as much as 3 and 1.2 optical depths, respectively.

The high resistance to UVR of the coastal phytoplankton assemblages from South China Sea waters is probably related to 2 main factors: first, their evolutionary light history allows cells to be naturally (e.g. genetically) acclimated to high radiation fluxes (Helbling et al. 1992) leading to low damage rates (Boelen et al. 2000, Helbling et al. 2001a); second, more effective mechanisms of acclimation and repair may take place in tropical sites. Although in Antarctic phytoplankton assemblages the presence of UV-absorbing compounds, such as mycosporine-like aminoacids (MAAs; Karentz et al. 1991b, Vernet et al. 1994, Helbling et al. 1996), has been proved, their protection role against UVR is sometimes partial or even uncertain for small cells such as those encountered in the tropical sites (Garcia-Pichel 1994). Indeed, repair mechanisms of DNA damage seem to be a common strategy in many aquatic environments to reduce the impact of UVR (Banaszak 2003). For example, studies carried out in Lake Titicaca have already demonstrated the importance of this process (Helbling et al. 2001a), with the presence of MAAs almost null in phytoplankton samples (Villafañe et al. 1999), as also seen in our experiments in China (data not shown). In fact, here we have determined that under experimental fast mixing conditions such as those imposed on our phytoplankton assemblages, cells will have more frequent periods of being exposed to low/high irradiances (i.e. rotating within the UML), probably providing favorable conditions to repair any DNA damage produced by UVR. The high frequency of low irradiance periods would thus allow repair to overcome damage rates. This would be especially important for our assemblages dominated by relatively small cells $(<10 \mu \mathrm{m})$, which are known to be vulnerable to DNA damage produced by UV-B (Boelen et al. 2000, Buma et al. 2001). The size distribution of cells, in addition, would also explain the relatively high resistance of our tropical assemblages, as it is known that although small cells are more susceptible to DNA damage, they are more resistant to photosynthesis inhibition (Buma et al. 2001, Helbling et al. 2001b). This uncoupling is thought to be related to the fact that different targets (i.e. the DNA and photosynthetic apparatus) are affected by UVR in different ways (Helbling et al. 2001b).

In this study we have demonstrated that fast mixing favors phytoplankton assemblages when exposed to UVR. As tropical environments have a relatively stable UML (Kara et al. 2000) dynamic (i.e. reversible), as opposed to chronic, inhibition seems to take place, and fast rotation minimizes the negative impact of UVR and even benefits the cells. Also, these favorable mixing conditions allow cells to overcome UVR-induced DNA damage produced under high radiation conditions. Thus, we conclude that the interaction of fast mixing and high-level solar UVR in these tropical 
coastal environments might result in higher integrated productivity than previously thought. Therefore, the application of models constructed with data obtained from other areas of the world can probably not be applied directly to tropical phytoplankton, and thus, modeling efforts should take into account these differential responses of organisms when considering the interactive effects of UVR and mixing.

Acknowledgements. We thank personnel at Nan'Ao Station for logistic support. H. Zagarese (Instituto Tecnológico de Chascomús, Argentina) provided valuable comments on early versions of this paper. We thank the suggestions of 3 anonymous reviewers that helped to improve the manuscript. This work was supported by University of Shantou, CONICET (PIP $\mathrm{N}^{\circ}$ 457/98) and Fundación Playa Unión. This is contribution \#50 of Estación de Fotobiología Playa Unión.

\section{LITERATURE CITED}

Banaszak AT (2003) Photoprotective physiological and biochemical responses of aquatic organisms to UVR. In: Helbling EW, Zagarese HE (eds) UV effects in aquatic organisms and ecosystems. The Royal Society of Chemistry, Cambridge, p 329-356

Barbieri ES, Villafañe VE, Helbling EW (2002) Experimental assessment of UV effects upon temperate marine phytoplankton when exposed to variable radiation regimes. Limnol Oceanogr 47:1648-1655

Boelen P, de Boer MK, Kraay GW, Veldhuis MJW, Buma AGJ (2000) UVBR-induced DNA damage in natural marine picoplankton assemblages in the tropical Atlantic Ocean. Mar Ecol Prog Ser 193:1-9

Buma AGJ, Helbling EW, de Boer MK, Villafañe VE (2001) Patterns of DNA damage and photoinhibition in temperate South-Atlantic picophytoplankton exposed to solar ultraviolet radiation. J Photochem Photobiol B: Biol 62: $9-18$

Cabrera S, López M, Tartarotti B (1997) Phytoplankton and zooplankton response to ultraviolet radiation in a highaltitude Andean lake: short- versus long-term effects. J Plankton Res 19:1565-1582

Figueroa FL, Salles S, Aguilera J, Jiménez C, Mercado J, Viñegla B, Flores-Moya A, Altamirano M (1997) Effects of solar radiation on photoinhibition and pigmentation in the red alga Porphyra leucosticta. Mar Ecol Prog Ser 151: $81-90$

Garcia-Pichel F (1994) A model for internal shelf-shading in planktonic organisms and its implications for the usefulness of ultraviolet sunscreens. Limnol Oceanogr 39: $1704-1717$

Häder DP (1997) Effects of UV radiation on phytoplankton. In: Jones JG (ed) Advances in microbial ecology. Plenum Press, New York, p 1-26

Häder DP, Lebert M, Marangoni R, Colombetti G (1999) ELDONET - European Light Dosimeter Network hardware and software. J Photochem Photobiol B Biol 52:51-58

Helbling EW, Villafañe VE, Ferrario ME, Holm-Hansen O (1992) Impact of natural ultraviolet radiation on rates of photosynthesis and on specific marine phytoplankton species. Mar Ecol Prog Ser 80:89-100

Helbling EW, Villafañe VE, Holm-Hansen O (1994) Effects of ultraviolet radiation on Antarctic marine phytoplankton photosynthesis with particular attention to the influence of mixing. In: Weiler CS, Penhale PA (eds) Ultraviolet radiation in Antarctica: measurements and biological effects. American Geophysical Union, Washington, DC, p 207-227

Helbling EW, Chalker BE, Dunlap WC, Holm-Hansen O, Villafañe VE (1996) Photoacclimation of antarctic marine diatoms to solar ultraviolet radiation. J Exp Mar Biol Ecol 204:85-101

Helbling EW, Villafañe VE, Buma AGJ, Andrade M, Zaratti F (2001a) DNA damage and photosynthetic inhibition induced by solar UVR in tropical phytoplankton (Lake Titicaca, Bolivia). Eur J Phycol 36:157-166

Helbling EW, Buma AGJ, de Boer MK, Villafañe VE (2001b) In situ impact of solar ultraviolet radiation on photosynthesis and DNA in temperate marine phytoplankton. Mar Ecol Prog Ser 211:43-49

Holm-Hansen O, Helbling EW (1995) Técnicas para la medición de la productividad primaria en el fitoplancton. In: Alveal K, Ferrario ME, Oliveira EC, Sar E (eds) Manual de métodos ficológicos. Universidad de Concepción, Concepción, Chile, p 329-350

Kara AB, Rochford PA, Hurlburt HE (2000) An optimal definition for ocean mixed layer depth. J Geophys Res 105: 16803-16821

Karentz D, Cleaver JE, Mitchell DL (1991a) Cell survival characteristics and molecular responses of Antarctic phytoplankton to ultraviolet-B radiation. J Phycol 27:326-341

Karentz D, McEuen FS, Land MC, Dunlap WC (1991b) Survey of mycosporine-like amino acid compounds in Antarctic marine organisms: potential protection from ultraviolet exposure. Mar Biol 108:157-166

Köhler J, Schmitt M, Krumbeck H, Kapfer M, Litchmann E, Neale PJ (2001) Effects of UV on carbon assimilation of phytoplankton in a mixed water column. Aquat Sci 63: 294-309

Madronich S (1993) The atmosphere and UV-B radiation at ground level. In: Young AR, Björn LO, Moan J, Nultsch W (eds) Environmental UV photobiology. Plenum Press, New York, p 1-39

Marra J (1978) Phytoplankton photosynthetic response to vertical movement in a mixed layer. Mar Biol 46:203-208

Neale PJ (1987) Algal photoinhibition and photosynthesis in the aquatic environment. In: Kyle DJ, Osmond CB, Arntzen CJ (eds) Photoinhibition. Elsevier, Amsterdam, p 39-65

Neale PJ, Kieber DJ (2000) Assessing biological and chemical effects of UV in the marine environment: spectral weighting functions. In: Hester RE, Harrison RM (eds) Causes and environmental implications of increased UV$B$ radiation. The Royal Society of Chemistry, Cambridge, p 61-83

Neale PJ, Lesser MP, Cullen JJ (1994) Effects of ultraviolet radiation on the photosynthesis of phytoplankton in the vicinity of McMurdo station, Antarctica. In: Weiler CS, Penhale PA (eds) Ultraviolet radiation in Antarctica: measurements and biological effects. Antarctic Research Series, Vol 62. American Geophisical Union, Washington, DC, p 125-142

Neale PJ, Davis RF, Cullen JJ (1998) Interactive effects of ozone depletion and vertical mixing on photosynthesis of Antarctic phytoplankton. Nature 392:585-589

Neale PJ, Helbling EW, Zagarese HE (2003) Modulation of UVR exposure and effects by vertical mixing and advection. In: Helbling EW, Zagarese HE (eds) UV effects in aquatic organisms and ecosystems. The Royal Society of Chemistry, Cambridge, p 107-134 
Neori A, Vernet M, Holm-Hansen O, Haxo FT (1986) Relationship between action spectra for chlorophyll a fluorescence and photosynthetic $\mathrm{O}_{2}$ evolution in algae. J Plankton Res 8:537-548

Neori A, Vernet M, Holm-Hansen O, Haxo FT (1988) Comparison of chlorophyll far-red and red fluorescence excitation spectra with photosynthetic oxygen action spectra for photosystem II in algae. Mar Ecol Prog Ser 44:297-302

Nilawati J, Greenberg BM, Smith REH (1997) Influence of ultraviolet radiation on growth and photosynthesis of two cold ocean diatoms. J Phycol 33:215-224

Rozema J, van Geel B, Björn LO, Lean J, Madronich S (2002) Toward solving the UV puzzle. Science 296:1621-1622

Ruggaber A, Dlugi R, Nakajima T (1994) Modelling of radiation quantities and photolysis frequencies in the troposphere. J Atmos Chem 18:171-210

Rundel RD (1983) Action spectra and estimation of biologically effective UV radiation. Physiol Plant 58:360-366

Smith RC, Prézelin BB, Baker KS, Bidigare RR and 9 others (1992) Ozone depletion: ultraviolet radiation and phytoplankton biology in Antarctic waters. Science 255: 952-959

Utermöhl H (1958) Zur Vervollkommnung der quantitativen Phytoplankton-Methodik. Int Ver Theor Angew Limnol 9: 1-38

Vernet M, Brody EA, Holm-Hansen O, Mitchell BG (1994) The response of Antarctic phytoplankton to ultraviolet radiation: absorption, photosynthesis, and taxonomic composition. In: Weiler CS, Penhale PA (eds) Ultraviolet radiation in Antarctica: measurements and biological effects. American Geophysical Union, Washington, DC, p 143-158

Editorial responsibility: Otto Kinne (Editor), Oldendorf/Luhe, Germany
Villafañe VE, Reid FMH (1995) Métodos de microscopía para la cuantificación del fitoplancton. In: Alveal K, Ferrario ME, Oliveira EC, Sar E (eds) Manual de métodos ficológicos. Universidad de Concepción, Concepción, Chile, p 169-185

Villafañe VE, Andrade M, Lairana V, Zaratti F, Helbling EW (1999) Inhibition of phytoplankton photosynthesis by solar ultraviolet radiation: studies in Lake Titicaca, Bolivia. Freshw Biol 42:215-224

Villafañe VE, Helbling EW, Zagarese HE (2001) Solar ultraviolet radiation and its impact on aquatic systems of Patagonia, South America. Ambio 30:112-117

Villafañe VE, Sundbäck K, Figueroa FL, Helbling EW (2003) Photosynthesis in the aquatic environment as affected by UVR. In: Helbling EW, Zagarese HE (eds) UV effects in aquatic organisms and ecosystems. The Royal Society of Chemistry, Cambridge, p 357-397

Vincent WF, Neale PJ (2000) Mechanisms of UV damage to aquatic organisms. In: De Mora S, Demers S, Vernet M (eds) The effects of UV radiation in the marine environment. Cambridge Environmental Chemistry Series 10. Cambridge University Press, Cambridge, p 149-176

Wellburn AR (1994) The spectral determination of chlorophylls $a$ and $b$, as well as total carotenoids, using various solvents with spectrophotometers of different resolution. J Plant Physiol 144:307-313

Williamson CE, Stemberger RS, Morris DP, Frost TM, Paulsen SG (1996) Ultraviolet radiation in North American lakes: attenuation estimates from DOC measurements and implications for plankton communities. Limnol Oceanogr 41: 1024-1034

Submitted: January 3, 2002; Accepted: June 13, 2003 Proofs received from author(s): September 2, 2003 